\title{
Cultural adaptation of The End-Stage Renal Disease Adherence Questionnaire for hemodialysis patients
}

\author{
Adaptação cultural do questionário de adesão do paciente renal crônico em hemodiálise \\ Adaptación cultural del cuestionario de adhesión del paciente renal crónico en hemodiálisis
}

\begin{abstract}
Silvia Maria de Sá Basilio Lins', Josete Luzia Leite', Simone de Godoy", Patrícia dos Santos Claro Fuly"I, Silvia Teresa Carvalho de Araújo ${ }^{\text {Iv }}$, Ítalo Rodolfo Silva'

'Universidade Federal do Rio de Janeiro, Anna Nery Nursing School, Postgraduate Program in Nursing. Rio de Janeiro, Brazil.

"Universidade de São Paulo, School of Nursing of Ribeirão Preto,

Department of General and Specialized Nursing. Ribeirão Preto, São Paulo, Brazil.

III Universidade Federal Fluminense, School of Nursing Aurora de Afonso Costa,

Department of Surgical Medical Nursing. Rio de Janeiro, Brazil.

Iv Universidade Federal do Rio de Janeiro, Anna Nery Nursing School,

Department of Surgical Medical Nursing. Rio de Janeiro, Brazil.
\end{abstract}

\section{How to cite this article:}

Lins SMSB, Leite JL, Godoy S, Fuly PSC, Araújo STC, Silva IR. Cultural adaptation of The End-Stage

Renal Disease Adherence Questionnaire for hemodialysis patients. Rev Bras Enferm [Internet]. 2017;70(6):1169-75.

DOI: http://dx.doi.org/10.1590/0034-7167-2016-0519

Submission: 09-23-2016 Approval: 01-27-2017

\section{ABSTRACT}

Objective: To describe the stages in the cultural adaptation of "The End-Stage Renal Disease Adherence Questionnaire" for use in Brazil. Method: A descriptive, transversal study with a quantitative approach. The cultural adaptation followed the steps of translation, professional committee, back translation, panel of patients and pretest. Results: the translation stage created a version in Portuguese that was analyzed by specialists, who suggested alterations in the title, seven sentences in the questions and three sets of answers. In the panel of patients phase, two questions were altered. The back translation considered the original characteristics of the instrument were maintained, likewise there were no modifications in the pretest phase. The third version written in Portuguese was considered to be the final version of the questionnaire. Conclusion: this instrument should facilitate nursing care management in hemodialysis, enabling the monitoring of adherence among these patients and also contribute to improving the indicators of morbidity and mortality.

Descriptors: Patient Cooperation; Adherence to Medication; Chronic Renal Insufficiency; Hemodialysis; Nephrology Nursing.

\section{RESUMO}

Objetivo: Descrever as etapas da adaptação cultural do The End-Stage Renal Disease Adherence Questionnaire para uso no Brasil. Método: Estudo descritivo, transversal, com abordagem quantitativa. A adaptação cultural seguiu as etapas de tradução, comitê de especialistas, retrotradução, painel de pacientes e pré-teste. Resultados: A etapa de tradução gerou uma versão em português, analisada por especialistas, que sugeriram alterações no título, em sete sentenças de perguntas e em três conjuntos de respostas. Na fase de painel de pacientes, duas perguntas sofreram alterações. A retrotradução considerou a manutenção das características originais do instrumento, assim como não houve modificação na fase de pré-teste. A terceira versão produzida em português foi considerada a versão final do questionário. Conclusão: Este instrumento deverá facilitar o gerenciamento do cuidado de enfermagem na hemodiálise, permitindo a monitorização da prática de adesão dos pacientes e ainda contribuindo para a melhoria de indicadores de morbidade e mortalidade. Descritores: Cooperação do Paciente; Adesão à Medicação; Insuficiência Renal Crônica; Diálise Renal; Enfermagem em Nefrologia.

\section{RESUMEN}

Objetivo: Describir las etapas de la adaptación cultural de The End-Stage Renal DiseaseAdherenceQuestionnaire para uso en Brasil. Método: Estudio descriptivo, transversal, con abordaje cuantitativa. La adaptación cultural siguió las etapas de traducción, comité de especialistas, retrotraducción, panel de pacientes y pre pruesta. Resultados: La etapa de traducción generó una versión en portugués, analizada por especialistas, que sugirieron alteraciones en el título, en siete sentencias de preguntas y en tres conjuntos de respuestas. En la fase de panel de pacientes, dos preguntas sufrieron alteraciones. La retrotraducción consideró la manutención de las características originales del instrumento, así como no hubo modificaciones en la fase de pre prueba. La tercera versión producida en portugués 
fue considerada la versión final del cuestionario. Conclusión: Este instrumento deberá facilitar la gestión de cuidado de enfermería en la hemodiálisis, permitiendo la monitoreo de la práctica de adhesión de los pacientes y todavía contribuyendo para la mejoría de indicadores de morbilidad y mortalidad.

Descriptores: Cooperación del Paciente; Adhesión a la Medicación; Insuficiencia Renal Crónica; Diálisis Renal; Enfermería en Nefrología.

\section{CORRESPONDING AUTHOR Silvia Maria de Sá Basilio Lins E-mail: silviamarialins@gmail.com}

\section{INTRODUCTION}

Chronic renal disease (CRD) demands modifications to personal habits and influences the individual's quality of life. Faced with a complex treatment, it is fundamental that the patient assumes a protagonistic role for this challenge. Faced with the impossibility of recovering from the pathological condition, it is essential that the patients perceive themselves to be an active being and capable of self-empowerment in their current life circumstances ${ }^{(1)}$. CRD presents progressively and irreversibly, until reaching its more advanced stages, when it promotes anatomical and physiological changes, as well as psychological and social alterations ${ }^{(2)}$.

It is possible that the renal patient, in the last level of disease evolution, has many signs and symptoms remedied. Therefore, it is necessary to perform a renal replacement therapy as well as a drug, dietetic and water diet. In Brazil, approximately $90 \%$ of patients undergo hemodialysis as dialytic therapy, due to the greater provision of this therapeutic modality by the SUS [Unified Health System] ${ }^{(3)}$.

Compliance with this therapeutic regimen is patient-dependent, that is, it requires that the individual maintains adherence to the therapy. Adherence is defined as the degree of compliance between the recommendations prescribed by the health professionals and the following of these by the patients ${ }^{(4)}$. However, non-adherence to treatment among patients with chronic non-transmissible conditions is estimated to be $50 \%{ }^{(5)}$.

In a study investigating the adherence of renal patients to drug therapy, it was found that $55.4 \%$ of the interviewees were non-adherent ${ }^{(6)}$; In another study, $50 \%$ of patients reported not adhering to fluid intake and $44 \%$ did not follow dietary recommendations ${ }^{(7)}$. Studies aiming to quantify the adherence of these patients usually encounter a difficulty common to all of them: the impossibility of comparing their results, since a variety of methods had been used to collect the data.

A precise evaluation of adherence behavior is fundamental for care planning, enabling changes and adaptations in the prescribed recommendations ${ }^{(5)}$. To do this, it is necessary to have a valid and reliable instrument. In the literature, there are several instruments available to measure the degree of adherence, but there is no gold standard ${ }^{(8)}$. The methodology used to measure adherence should allow a correlation between the results found and the effects produced by the actions implemented on the basis of these results ${ }^{(8)}$.

When the instruments available for assessing the specific adherence of the renal patient on hemodialysis are limited, there are two internationally used scales: the Dialysis Diet and Fluid Non-Adherence Questionnaire (DDFQ), which measures the liquid and dietary aspects of treatment ${ }^{(9)}$ and The End-Stage Renal Disease Adherence Questionnaire (ESRD$A Q)$. The ESRD-AQ is a self-report instrument developed in Los Angeles, USA, which, in addition to validly and reliably measuring adherence behavior to the four aspects of treatment (hemodialysis, fluid intake, diet and medication), it also evaluates the individual's perception of adherence and the reasons underlying their adherent/non-adherent behavior ${ }^{(8)}$.

The ESRD-AQ items were prepared based on the literature and consultation with specialists. Its final version consists of 46 questions divided into five sections - general information, hemodialysis, medication, fluid restriction and diet. The answers contained in the instrument use a combination of the Likert scale, multiple-choice, and yes/no responses. Adherence itself is evaluated in six questions, in which the patients receive a score according to their answers: the greater the adherence, the more points and vice versa. Another eight questions cover their perception and knowledge of the treatment ${ }^{(8)}$.

Using this type of tool facilitates the management of nursing care and contributes to the strengthening of the professional-patient relationship, which is considered a variable that can influence negatively or positively the individual' adherence practices. Strengthened relationships allow therapeutic alternatives to be explored and negotiated with the ultimate goal of promoting adherence, which should be discussed on a constant basis ${ }^{(5)}$.

When a search was carried out in the LILACS, MEDLINE and CINHAL databases, with the objective of exploring the topic of adherence to therapy among renal hemodialysis patients, it was found that there is no instrument specifically constructed for this clientele in Brazil. Brazilian researchers usually use tools that are generic and that address only a single aspect of therapy.

In the dialysis clinics where patients undergo HD, the nurse/patient ratio is $1: 35^{(10)}$ consequently, management of the therapeutic regimen tends to be facilitated by the use of this type of technological device, contributing to lower morbidity and mortality rates for patients on hemodialysis. In Brazil, the mortality rate in 2010 was $19.9 \%$, which is considered high ${ }^{(3)}$.

According to the National Kidney Foundation, the ideal dose of hemodialysis has already been established: urea removal rate $(\mathrm{Kt} / \mathrm{V})$ greater than 1.2, and a frequency of three weekly HD sessions with a time of 4 hours each ${ }^{(11)}$. Thus, in order to achieve a reduction in the mortality rate, it is necessary to focus the research in other areas, including the patient's adherence to the proposed therapeutic regimen. In its agenda of research priorities, Brazil encourages studies that may contribute to reductions in mortality and morbidity rates in this specific population ${ }^{(12)}$.

In view of the above, the present article aims to describe each of the steps in the cultural adaptation of The End-Stage Renal Disease Adherence Questionnaire for use in Brazil.

\section{METHOD}

\section{Ethical aspects}

After authorization from the researcher who produced the original version of the ESRD-AQ questionnaire, this 
study was submitted and approved by the Research Ethics Committee of the Anna Nery School of Nursing. All the recommendations of Resolution 466/12 of the National Health Council were followed. Participants signed the Free and Informed Consent Form, and were informed about the risks in the research.

\section{Study design, location and period}

Descriptive, cross-sectional study with a quantitative approach. The research was carried out at two dialysis centers, in the cities of Itaboraí and Niterói, both in the State of Rio de Janeiro. The period for data collection was from June to August, 2014.

\section{Population or sample; inclusion and exclusion criteria}

The professional committee was formed by eight specialists in Nephrology, the inclusion criteria for which were time of experience greater than two years, post-graduation in $\mathrm{Ne}$ phrology and a university professor with experience in the process of cultural adaptation.

In the "panel of patients" and "pre-test" stages, the participants were patients from the dialysis clinics (who are in fact the target population of the study) were chosen using the random number generator tool in Excel. The inclusion criteria for participation were: to be on HD for more than three months; to undergo HD three times a week for three to four hours; age over 18; to be independent in terms of being able to perform activities such as walking and feeding; be literate; and to have no cognitive deficit.

\section{Study protocol}

The cultural adaptation process ${ }^{(13)}$ followed the methodology outlined in Figure 1.

\section{Phase 1 - Translation of the original text}

The scale, in its Original Version, was translated by a Brazilian who holds a certificate of sworn translator for English - and by the principal researcher. Two versions were generated, the Portuguese Version 1 and Portuguese Version 2, which were analyzed by the researchers together for discussion and selection of the best sentences, which gave rise to the Portuguese Consensus Version 1. The translation was performed by a person familiar with both the subject matter and research objectives, as well as by a person who did not have such knowledge. In this way, a more precise restitution was promoted, which enabled the capture of unexpected meanings ${ }^{(14)}$.

\section{Phase 2 - Evaluation of the consensus version by the profes- sional committee}

The Portuguese Consensus 1 was then submitted to a committee composed of specialists, who received an instrument containing the English and Portuguese versions of each question/answer, in order to evaluate the semantic, conceptual, idiomatic and experimental equivalence of the instrument. The committee comprised nine specialists. Of these, five developed care activities, three worked in teaching and one in care/teaching - there were six nurses and three doctors. Two of them possessed the title of specialist, three possessed a master's degree and four were doctors.

In the Semantic Equivalence, the meaning of the words was evaluated, since grammatical changes could occur; In Idiomatic Equivalence, the colloquialisms were verified, since these, in general, are not translated literally and are replaced by local expressions; In Experimental, the adjustment to situations experienced locally was analyzed; And Conceptual Equivalence, which checked whether the concepts expressed represented the events experienced by the individual ${ }^{(14)}$.

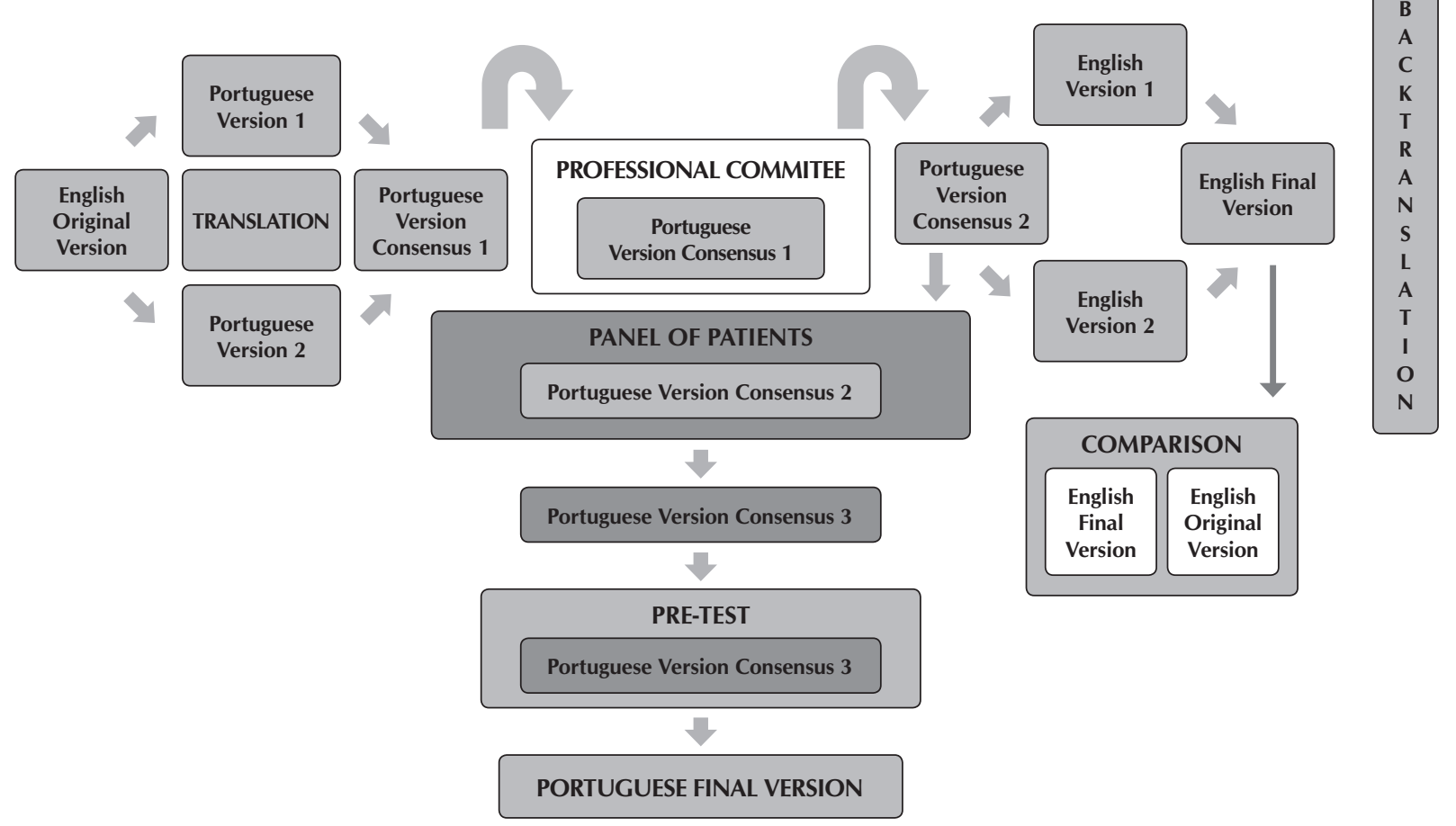

Figure 1 - Process for the translation of The End-Stage Renal Disease Adherence Questionnaire into Portuguese 
As for the equivalences, the specialists were instructed to assign the number +1 when they considered the Portuguese translation to be equivalent in all its aspects (semantic, conceptual, idiomatic and experimental); number 0 when they had doubts about the translation; and number -1 when they considered that equivalence had not been achieved. Whenever the number 0 or -1 was assigned, the specialist was requested to explain the reasons why and suggest the necessary changes. The sentences were considered equivalent when a number equal to or greater than $80 \%$ of the specialists attributed the +1 note. The sentences that did not reach this agreement index were reviewed by the researchers, so that the suggestions proposed by the specialists were incorporated. Thus, the Portuguese Consensus Version 2 was prepared and then submitted to two parallel procedures.

\section{Phase 3 - Back translation}

The back-translation of the Portuguese Consensus Version 2 was carried out by two independent translators, whose native language is American English, creating the English Version 1 and English Version 2. Next, these were compared by the researchers giving rise to the English Final Version, which was in turn compared to the original version by a third translator of American origin, who attested to the maintenance of the original instrument's characteristics.

\section{Phase 4 - Evaluation of the consensus version by the panel of patients}

The Portuguese Consensus Version 2 was also submitted to the target population, when an uneven number of patients (three) were defined for each of the four domains of the instrument (HD, drugs, fluids and diet). Thus, 12 subjects were chosen by the Excel random number generator and the inclusion criteria were respected in the research.

The next step was the individual approach to each participant, explaining the objectives of the research and informing that the instrument should be read and answered by the patient, so that the researcher would be available for clarification of any issues. In view of the difficulty presented by the patients who had one of their upper limbs immobilized by the Arteriovenous Fistula (AVF) puncture the researcher was also responsible for marking the chosen alternative.

Participants read and answered the questionnaire, while the researcher inquired about three key points: 1 - Is there a word or phrase that you did not understand? 2 - Do you have any suggestions to facilitate understanding of the questionnaire? 3 - How do you rate the level of difficulty to answer this instrument: easy, medium or difficult? The patients' suggestions were analyzed by the researchers and when considered pertinent and accepted, the text was duly altered thereby originating the Portuguese Consensus Version 3.

\section{Phase 5 - Application of the pre-test}

Considering that, after cultural adaptation the instrument would be submitted to the validation process, in which it was intended to approach 80 individuals, a sample size of $10 \%$ of this value was established for the pre-test. Therefore, the Portuguese Consensus Version 3 was submitted to 8 patients, also chosen at random. This time, no questions were asked about the understanding of the instrument, to ensure that any questions would be spontaneous. There was no need for further changes, thus the Portuguese Consensus Version 3 was then denominated the Portuguese Final Version.

\section{Analysis of the results}

The data were analyzed by simple descriptive statistics and evaluation of the semantic, conceptual, idiomatic and experimental equivalences.

\section{RESULTS}

The evaluators analyzed the following components of the questionnaire: title; instructions; and all 46 sentences of questions and corresponding 46 sets of answers. From this evaluation, 28 (61\%) questions and 31 (67\%) answers obtained 100\% agreement, that is, the nine specialists considered them equivalent. Another 11 (24\%) questions, 12 (26\%) answers and the instructions obtained agreement of eight specialists, that is, $89 \%$ of the participants. On the other hand, seven questions (15\%) (Chart 1) and three responses (7\%) (Chart 2) were considered not equivalent and did not reach a minimum of $80 \%$ agreement. These were revised in accordance with the suggestions of the participants.

Chart 1 - Modifications to the questions as suggested by the professional committee for the Portuguese Consensus Version 1 of the questionnaire to evaluate the adherence of chronic renal disease patients to hemodialysis, Rio de Janeiro, Brazil, 2015

\begin{tabular}{|c|c|c|}
\hline Item & $\begin{array}{c}\text { Portuguese version } \\
\text { consensus 1 }\end{array}$ & $\begin{array}{c}\text { Portuguese version } \\
\text { consensus 2 }\end{array}$ \\
\hline $\begin{array}{c}\text { Question } \\
N^{\circ} 7\end{array}$ & $\begin{array}{c}\text { How long should each } \\
\text { dialysis session last? }\end{array}$ & $\begin{array}{c}\text { How long does each } \\
\text { of the hemodialysis } \\
\text { sessions last? }\end{array}$ \\
\hline $\begin{array}{c}\text { Question } \\
N^{\circ} 13\end{array}$ & $\begin{array}{c}\text { What level of difficulty } \\
\text { have you had to stay for } \\
\text { the entire hemodialysis } \\
\text { session? }\end{array}$ & $\begin{array}{c}\text { How much difficulty } \\
\text { have you had to stay for } \\
\text { the entire hemodialysis } \\
\text { session? }\end{array}$ \\
\hline $\begin{array}{c}\text { No } 16 \\
\text { (Reply to this question if } \\
\text { you answered "I did not } \\
\text { want to go" in the previous } \\
\text { question) }\end{array}$ & $\begin{array}{c}\text { Why did you not want } \\
\text { to go to the clinic for } \\
\text { hemodialysis? (Choose the } \\
\text { answer which best applies } \\
\text { to you) }\end{array}$ & $\begin{array}{c}\text { (Reply to this question } \\
\text { if you answered "I did } \\
\text { not want to go or I could } \\
\text { not go" in the previous } \\
\text { question) } \\
\text { Why did you not want to } \\
\text { go to the dialysis center? } \\
\text { (Choose the answer } \\
\text { which best applies to you) }\end{array}$ \\
\hline $\begin{array}{c}\text { Question } \\
N^{\circ} 17\end{array}$ & $\begin{array}{c}\text { During the last month, } \\
\text { how many times have } \\
\text { you shortened your } \\
\text { dialysis time? }\end{array}$ & $\begin{array}{c}\text { During the last month, } \\
\text { how many times did you } \\
\text { ask for the dialysis time } \\
\text { to be shortened? }\end{array}$ \\
\hline $\begin{array}{c}\text { During the last month, } \\
\text { minutes, on average, did } \\
\text { you take from the sessions? }\end{array}$ & $\begin{array}{c}\text { During the last month, } \\
\text { when the dialysis time } \\
\text { was reduced, this } \\
\text { reduction was by how } \\
\text { many minutes? }\end{array}$ \\
\hline
\end{tabular}

To be continued 
Chart 1 (concluded)

\begin{tabular}{|c|c|c|}
\hline Item & $\begin{array}{c}\text { Portuguese version } \\
\text { consensus 1 }\end{array}$ & $\begin{array}{c}\text { Portuguese version } \\
\text { consensus 2 }\end{array}$ \\
\hline $\begin{array}{c}\text { Question } \\
N^{\circ} 19\end{array}$ & $\begin{array}{c}\text { What was the main motive } \\
\text { for you to shorten your HD } \\
\text { time? }\end{array}$ & $\begin{array}{c}\text { What was the main } \\
\text { motive for the reduction } \\
\text { in your HD time? }\end{array}$ \\
\hline $\begin{array}{c}\text { Question } \\
\text { in } 44\end{array}$ & $\begin{array}{c}\text { What level of difficulty } \\
\text { have you had to } \\
\text { follow your dietary } \\
\text { recommendations? }\end{array}$ & $\begin{array}{c}\text { How much difficulty } \\
\text { have you had to } \\
\text { follow your dietary } \\
\text { recommendations? }\end{array}$ \\
\hline
\end{tabular}

Note: *HD: hemodialysis.

Chart 2 - Modifications to the answers as suggested by the professional committee for the Portuguese Consensus Version 1 of the questionnaire to evaluate the adherence of chronic renal disease patients to hemodialysis, Rio de Janeiro, Brazil, 2015

\begin{tabular}{|c|c|c|}
\hline Item & $\begin{array}{l}\text { Portuguese version } \\
\text { consensus } 1\end{array}$ & $\begin{array}{l}\text { Portuguese version } \\
\text { consensus } 2\end{array}$ \\
\hline Title & $\begin{array}{l}\text { The End-Stage Renal } \\
\text { Disease Adherence } \\
\text { Questionnaire } \\
\text { (ESRD-AQ)* }\end{array}$ & $\begin{array}{l}\text { Questionnaire for the } \\
\text { evaluation of adherence } \\
\text { in chronic renal disease } \\
\text { patients on dialysis } \\
\text { (ESRD-AQ) }\end{array}$ \\
\hline $\begin{array}{l}\text { Answer } \\
N^{\circ} 7\end{array}$ & - 3 hours & $\begin{array}{c}\cdot \text { Less than } 3 \text { hours } \\
-3 \text { hours }\end{array}$ \\
\hline $\begin{array}{l}\text { Answer } \\
N^{\circ} 16\end{array}$ & $\begin{array}{c}\text { - Medical commitment } \\
\text { (appointment or exam) } \\
\text { - I did not want to go } \\
\text { (Answer the next question } \\
\text { \#16) }\end{array}$ & $\begin{array}{l}\text { - Medical attendance } \\
\text { (appointment or exam) } \\
\text { - I did not want to go or } \\
\text { could not go (Answer the } \\
\text { next question \#16) }\end{array}$ \\
\hline $\begin{array}{l}\text { Answer } \\
N^{\circ} 19\end{array}$ & $\begin{array}{l}\text { - Not applicable: I did not } \\
\text { reduce the time of any } \\
\text { HD** session } \\
\text { - Technical questions } \\
\text { related to hemodialysis. } \\
\text { What? For example, low } \\
\text { blood flow, coagulation } \\
\text { of the system, problem } \\
\text { in the hemodialysis } \\
\text { equipment, etc. }\end{array}$ & $\begin{array}{l}\text { - Not applicable: there } \\
\text { was no reduction in the } \\
\text { time of any HD session } \\
\text { - Decision by a care } \\
\text { professional (Why? Please } \\
\text { explain: for example, low } \\
\text { blood flow, coagulation } \\
\text { of the system, problem } \\
\text { in the hemodialysis } \\
\text { equipment, etc. }\end{array}$ \\
\hline
\end{tabular}

Note: * ESRD-AO: The End-Stage Renal Disease Adherence Questionnaire **HD: Hemodialysis.

Having made the changes suggested by the specialists, the Portuguese Consensus Version 1 gave rise to the Portuguese Consensus Version 2, which was sent for the back-translation process. In this, English Version 1 and English Version 2 were produced, which were then submitted to analysis by the researchers and resulted in the English Version Consensus 1. This was compared to the original version of the instrument and it was confirmed by a third American translator that the characteristics of the original instrument had been maintained in this version and that the cultural adaptation did not compromise the essence of the questionnaire. The American translator made the following consideration: "The files are compatible, using different language styles - no problem at all to observe."
The Portuguese Consensus Version 2 was also submitted to an evaluation by 12 patients, again selected at random. Of these, four had not completed Elementary School level education; One had completed Elementary School; Four, incomplete high school; And three, completed High School. At the end of the participation, ten $(83 \%)$ participants stated that they understood all the words and phrases, had no suggestion to make and considered it easy. One $(8.5 \%)$ participant understood everything, did not make suggestions, but classified the difficulty level as medium considering the instrument was too lengthy. Finally, one (8.5\%) participant reported not having understood question number 31 and specifically the word "hydric", suggesting an alteration for this word/phrase, which was considered pertinent by the researchers (Figure 2 and Chart 3 ).

\section{Panel of Patients}

Understood all the words and phrases, did not make any suggestions and considered the instrument was easy

- Understood all the words and phrases, did not make any suggestions and considered the instrument was moderately difficult

Did not understand all the words/phrases, made a suggestion and considered the instrument was moderately difficult

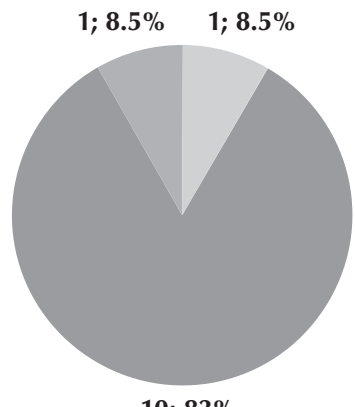

$10 ; 83 \%$
Figure 2 - Distribution of the opinions presented by the participants in the panel of patients, Rio de Janeiro, Brazil, 2015

Chart 3 - Modifications suggested by the panel of patients for the Portuguese Consensus Version 2 of the questionnaire to evaluate the adherence of chronic renal disease patients to hemodialysis, Rio de Janeiro, Brazil, 2015

\begin{tabular}{|c|l|l|}
\hline Item & \multicolumn{1}{|c|}{$\begin{array}{c}\text { Portuguese version } \\
\text { consensus 2 }\end{array}$} & $\begin{array}{c}\text { Portuguese version } \\
\text { consensus 3 }\end{array}$ \\
\hline $\begin{array}{l}\text { Question } \\
N^{\circ} 31\end{array}$ & $\begin{array}{l}\text { During the last week, } \\
\text { with what frequency } \\
\text { did you only ingest } \\
\text { the quantity of liquids } \\
\text { recommended for you? }\end{array}$ & $\begin{array}{l}\text { During the last week, } \\
\text { how often did you } \\
\text { follow the liquids } \\
\text { restriction recommended } \\
\text { for you? }\end{array}$ \\
\hline $\begin{array}{l}\text { Question } \\
\text { No36 } 36\end{array}$ & $\begin{array}{l}\text { If you had some } \\
\text { difficulty to follow the } \\
\text { hydric restriction, what } \\
\text { type of difficulty did you } \\
\text { have? }\end{array}$ & $\begin{array}{l}\text { If you had some } \\
\text { difficulty to follow the } \\
\text { liquids restriction, what } \\
\text { type of difficulty did you } \\
\text { have? }\end{array}$ \\
\hline
\end{tabular}

Following the changes suggested by the panel of patients, the Portuguese Consensus Version 2 gave rise to the Portuguese Consensus Version 3, which continued on to the pre-test phase. In this, eight patients were individually approached and were not questioned about the necessary changes to the instrument, since, if they occurred, these should be spontaneous. All 
patients read and answered the instrument, demonstrating clarity and understanding. No help was requested or suggestions made; consequently the Portuguese Version Consensus 3 was considered to be the final version in Portuguese.

On the part of the patients who participated in the cultural adaptation, the modifications appeared in a single question sentence and in one word. In all, there was a total of 20 patients, 12 in the stage denominated panel of patients, who were questioned about necessary modifications and eight patients in the pre-test phase, in which there was no such questioning. Of these 20 patients, only one suggested an alteration in the instrument, which was considered pertinent given that it came from an individual in the target population for which the questionnaire is intended. At this point, given that the patients suggested few modifications, the instrument was deemed accessible.

\section{DISCUSSION}

The cultural adaptation of an instrument is usually not a simple and easy process, because it demands not only the literal translation of words, but also respect for the culture of the individuals for whom the instrument is being translated ${ }^{(15)}$. Special attention should be paid to the translation of words and also to semantic, idiomatic, experimental and conceptual equivalences ${ }^{(14)}$.

In this study, a rigorous process of cultural adaptation was applied, involving the participation of sworn translators, both in English and in Portuguese, together with a committee formed by specialists in the subject covered that speak English/Portuguese and also the participation of patients who responded to the instrument on two different occasions, namely at the panel of patients and at the pre-test stages.

This painstaking process sought to ensure a reliable adaptation to the local culture, which took into account not only the linguistic, but also technical and conceptual aspects. Thus, the instrument was able to measure health situations, specifically in relation to the adherence of chronic renal patients to the therapeutic regimen ${ }^{(13)}$.

An example of this concern with cultural adaptation can be cited in the introduction of the term "transporte da prefeitura" [municipal transportation], which was not present in the original instrument. The same was also stated in the Portuguese Consensus Version 1, because in Brazil, municipal governments have an obligation to guarantee low-income patients access to treatment. Such that when this is not possible through the public transport system, the city hall of the municipality to which the patient belongs provides a vehicle for this purpose ${ }^{(16)}$.

Another adaptation came from a discrepancy reported by the professional committee in the sentence of question 17. The original version in English: "During the last month, how many times have you shortened your dialysis time?" had been literally translated into Portuguese in the Portuguese Consensus 1 Version as "Quantas vezes você diminuiu o tempo de hemodiálise?" However, the observation made by the specialists drew attention to the fact that, in Brazil, the patients do not decrease the time of hemodialysis themselves. On the contrary, they must ask a health professional, in general a nurse or nursing technician for this reduction. Therefore, following the suggestion of the experts, the sentence was altered accordingly in the Portuguese Consensus Version 2: "No mês passado, quantas vezes você pediu para reduzir o tempo de hemodiálise?" [During the last month, how many times did you ask for the dialysis time to be shortened?].

Similarly, the original English version of the ESRD-AQ was also translated into Spanish, again some adaptations were made seeking cultural adequacy. The expression "have you ever had" would be translated literally by the verb "recibido" [received] in Spanish, but instead "tenido" [had] was considered the best option because, despite a slight regional difference, it was better accepted by most of the Hispanics ${ }^{(17)}$. This fact corroborates the present study, since it ratifies that the version of the adapted questionnaire should not be a literal translation of words alone, but a translation that considers the culture and the semantic adaptations necessary for a clear understanding in the language and context of the target audience for which the version is intended.

In the present study, a cultural adaptation perspective denominated "universalist" was assumed, in which the literal translation of the words is not sufficient, therefore rendering it fundamental to investigate whether the proposed concepts exist in the new culture through the evaluation of the semantic, conceptual, experimental and idiomatic equivalences ${ }^{(18)}$. Thus, in the present work a meticulous tuning process has been performed, capable of contemplating the cultural context and the lifestyle of the Brazilian target population.

\section{Study limitations}

A limitation found for this study was the need for reading skills among the patients, which excluded the application of the instrument to the illiterate and visually impaired. In addition, the participants were mostly unavailable before or after $H D$, making it necessary for them to respond to the instrument during the dialysis procedure.

\section{Contribution to the field of nursing, health or public policy}

This research contributes to professional practice by providing a tool that assists in the management of nursing care for the detection of patients who are at risk of becoming or are already non-adherent to their treatment. Furthermore, it enables studies to focus on promoting adherence and improving CRD indicators.

\section{CONCLUSION}

The cultural adaptation of the instrument sought not only the literal translation of the words, but a verification of the semantic and cultural adequacy of the words. This rigorous process submitted the instrument to sworn translators, specialists in the subject and, principally, the target population; thus guaranteeing that the proposed Portuguese version of the "End-Stage Renal Disease Adherence Questionnaire" (ESRD$A Q$ ) is culturally adapted for use in Brazil.

A technological tool has been made available that is able to distinguish adherent and non-adherent patients and that allows the identification of which aspect of the treatment represents the greatest difficulty for the individual. However, further research using the instrument is recommended in order to validate its efficacy and applicability. 


\section{REFERENCES}

1. Silva AS, Silveira RS, Fernandes GFM, Lunardi VL, Backes VMS. [Perceptions and changes in the quality of life of patients submitted to hemodyalisis]. Rev Bras Enferm [Internet]. 2011[cited 2015 Nov 30];64(5):839-44. Available from: http://www.scielo.br/pdf/ reben/v64n5/a06v64n5.pdf Portuguese

2. Bastos MG, Bregman R, Kirsztajn GM. Doença Renal Crônica: frequente e grave, mas também prevenível e tratável. Rev Assoc Med Bras [Internet]. 2010 [cited 2015 Nov 30];56(2): 248-53. Available from: http://www.scielo.br/pdf/ramb/v56n2/a28v56n2.pdf

3. Sesso RC, Lopes AA, Thomé FS, Lugon JR, Santos DR. Brazilian Chronic Dialysis Survey 2013: trend analysis between 2011 and 2013. J Bras Nefrol [Internet]. 2014 [cited 2015 Nov 30];36(4): 476-81. Available from: http://www.scielo.br/pdf/jbn/v36n4/01012800-jbn-36-04-0476.pdf

4. Haynes RB, Ackloo E, Sahota N, McDonald HP, Yao X. Interventions for enhancing medication adherence. Cochrane Database Syst Rev[Internet]. 2008 [cited 2015 Nov 30];16(2):CD000011. Available from: http://www.ncbi.nlm.nih.gov/pubmed/18425859

5. World Health Organization (WHO). Adherence to long-term therapies: evidence for action[Internet]. Geneva: WHO; 2003[cited 2015 Nov 30]. Available from: http://apps.who.int/ medicinedocs/en/d/ss4883e/

6. Sgnaolin V, Prado AE, Figueiredo L. [Adherence to pharmacological treatment in adult patients undergoing hemodialysis]. J Bras Nefrol [Internet]. 2012 [cited 2015 Nov 30];34(2):109-16. Available from: http://www.scielo.br/pdf/jbn/v34n2/02.pdf Portuguese

7. Khalil AA, Frazier SK, Lennie TA, Sawaya BP. Depressive symptoms and dietary adherence in patients with end-stage renal disease. J Ren Care [Internet]. 2011 [cited 2015 Nov 30];37(1):30-9. Available from: http://www.ncbi.nlm.nih.gov/pubmed/21288315

8. Kim Y, Evangelista LS, Philips LR, Pavlish C, Kopple JD. The end-stage renal disease adherence questionnaire (ESRD-AQ): testing the psychometric properties in patients receiving In-center hemodialysis. Nephrol Nurs J [Internet]. 2010 [cited 2015 Nov 30];37(4):777-93. Available from: http://www.ncbi.nlm.nih.gov/pmc/articles/PMC3077091/

9. Vlaminck H, Maes B, Jacobs A, Reyntjens S, Evers G. The dialysis diet and fluid non-adherence questionnaire: validity testing of a self-report instrument for clinical practice. J Clin Nurs [Internet]. 2001[cited 2015 Nov 30];10(5):707-15. Available from: http:// www.ncbi.nlm.nih.gov/pubmed/11822521

10. Brasil. Ministério da Saúde. Portaria $n^{\circ}$ 389, de 13 de março de 2014. Define os critérios para a organização da linha de cuidado da Pessoa com Doença Renal Crônica (DRC) e institui incentivo financeiro de custeio destinado ao cuidado ambulatorial pré-dialítico[Internet]. 2014 [cited 2015 Nov 30]. Available from: http://bvsms.saude.gov.br/bvs/saudelegis/gm/2014/ prt0389_13_03_2014.html

11. National Kidney Foundation (NKF). Updates clinical practice guidelines and recommendations [Internet]. EUA: NKF; 2006 [cited 2015 Nov 30]. Available from: https:// www.kidney.org/sites/default/files/docs/12-50-0210_jag_dcp_guidelines-hd_oct06_ sectiona_ofc.pdf

12. Brasil. Ministério da Saúde. Agenda Nacional de Prioridades de Pesquisa em Saúde [Internet]. 2015 [cited 2015 Nov 30$]$ ]. Available from: http://bvsms.saude.gov.br/bvs/publicacoes/agenda_nacional_prioridades_2ed_3imp.pdf

13. Ferrer M, Alonso J, Prieto L, Plaza V, Monsó E, Marrades R et al. Validity and reliability of the St George's Respiratory Questionnaire after adaptation to a different language and culture: the Spanish example. Eur Respir J [Internet]. 1996 [cited 2015 Nov 30];9(6):1160-6. Available from: http://erj.ersjournals.com/content/erj/9/6/1160.full.pdf

14. Guillemin F, Bombardier C, Beaton D. Cross-cultural adaptation of health-related quality of life measures: literature review and proposed guidelines. J Clin Epidemiol [Internet]. 1993 [cited 2015 Nov 30];46(12):1417-32. Available from: http://www.ncbi.nlm. nih. gov/pubmed/8263569

15. Jensen R, Cruz DALM, Tesoro MG, Lopes MHBM. Translation and cultural adaptation for Brazil of the Developing Nurses' Thinking model. Rev Latino-Am Enfermagem [Internet]. 2014 [cited 2015 Nov 30];22(2):197-203. Available from: http://www. scielo.br/pdf/rlae/v22n2/pt 0104-1169-rlae-22-02-00197.pdf

16. Brasil. Ministério da Saúde. Portaria/SAS/No 055, de 24 de fevereiro de 1999. Dispõe sobre a rotina do Tratamento Fora de Domicílio no Sistema Único de Saúde - SUS, com inclusão dos procedimentos específicos na tabela de procedimentos do Sistema de Informações Ambulatoriais do SIA/SUS e dá outras providências[Internet]. 1999[cited 2015 Nov 30]. Available from: http://saude.es.gov.br/Media/sesa/TFD/Portaria\%20SAS\%20N\%C2\%BA\%2055\%20de\% 2024\%2002\% 201999.pdf

17. Kim Y, Evangelista LS. Development and cultural adaptation of the Spanish version of the End Stage Renal Disease Adherence Questionnaire (SESRD-AQ). Nephrol Nurs J [Internet]. 2013 [cited 2015 Oct 30];40(6):493-506. Available from: http://www.ncbi. nlm. nih.gov/pubmed/24579396

18. Reichenheim ME, Moraes CL. Operationalizing the cross-cultural adaptation of epidemological measurement instruments.. Rev Saúde Pública [Internet]. 2007 [cited 2015 Nov 30];41(4):665-73. Available from: http://www.scielo.br/pdf/rsp/v41n4/en_6294.pdf 